\title{
Relationship between heterosis and genetic divergence for phosphorus use efficiency and its components in tropical maize
}

\author{
Relação entre heterose e divergência genética para a eficiência no uso do fósforo e seus componentes \\ em milho tropical
}

\author{
Débora Santos CaixetaI Roberto Fritsche-Neto ${ }^{\text {II* }}$ Lorena Guimarães Batista $^{\text {III }}$ \\ Humberto Fanelli Carvalho ${ }^{\text {III }}$ Júlio César DoVale ${ }^{I}$ Éder Cristian Malta de Lanes $^{\text {IV }}$ \\ Glauco Vieira Miranda ${ }^{\text {II }}$
}

\begin{abstract}
The objective of this study was to determine the relationship between heterosis and genetic divergence for phosphorus use efficiency (PUE) in tropical maize. It was used two groups of genitors, each consisting of seven lines, contrasting with each other in the nitrogen and phosphorus use efficiency. It was obtained 41 hybrid combinations between these groups, which were evaluated in low phosphorus. Randomized complete block design with two replications was used. For obtaining the components of variance and the breeding values were used REML/BLUP method. In the genotyping of the parental lines were used 80 microsatellite markers. Through the correlation between genetic distance obtained by the markers and specific combining ability it was not possible to determine with accuracy by molecular markers, the crosses that produced hybrids with the highest heterosis for PUE. Thus, is possible to conclude that there is no relationship between genetic divergence and heterosis for phosphorus use efficiency and its components in tropical maize.
\end{abstract}

Key words: dissimilarity, abiotic stress, molecular markers, combining ability.

\section{RESUMO}

O objetivo deste estudo foi determinar a relação entre divergência genética e heterose para a eficiência no uso de fósforo (EUP) em milho tropical. Utilizaram-se dois grupos de genitores, compostos de sete linhagens cada, contrastantes entre si para as eficiências no uso de nitrogênio e fósforo.
Foram obtidas 41 combinações híbridas entre esses grupos, as quais foram avaliadas em baixo fósforo. Usou-se o delineamento em blocos ao acaso com duas repetições. A obtenção dos componentes de variância e valores genéticos foi realizada via REML/BLUP e, para genotipagem das linhagens genitoras, foram utilizados 80 marcadores microssatélites. Através da correlação entre a distância genética obtida pelos marcadores e a capacidade específica de combinação, observou-se não ser possível a determinação com acurácia, via marcadores moleculares, dos cruzamentos que produziram os híbridos com as maiores heteroses para EUP. Com isso, é possível concluir que não há relação entre divergência genética e heterose para eficiência no uso de fósforo e seus componentes em milho tropical.

Palavras-chave: dissimilaridade, estresse abiótico, marcadores moleculares, capacidade de combinação.

\section{INTRODUCTION}

The lines evaluation about their combination ability is one of the most expensive steps in a maize breeding program (GUIMARÃES et al., 2007). In this sense, estimates of genetic divergence between lines by molecular markers should contribute to the formation of heterotic groups identifying hybrid combinations of higher heterotic effect and higher heterozigose. So that, in their segregating generations,

IPrograma de Pós-graduação em Fitotecnia, Universidade Federal de Viçosa (UFV), Viçosa, MG, Brasil.

IIDepartamento de Fitotecnia, UFV, 36570-000, Viçosa, MG, Brasil. E-mail: roberto.neto@ufv.br. *Autor para correspondência. "IICurso de Agronomia, UFV, Viçosa, MG, Brasil.

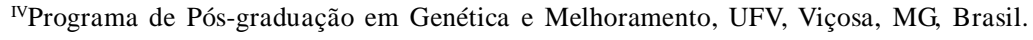


there is a greater chance of recoverying superior genotypes (LABORDA et al., 2005). The presence of genetic divergence among accessions of germplasm is essential; however, satisfactory results are obtained only if the germplasm employed in the cross also present high values for the traits of interest (CARVALHO et al., 2003). So, according to the theory of quantitative genetics, in any deviance of dominance higher than zero, heterosis is due to the allele frequency between the genitors, and there is a positive correlation between genetic divergence and heterosis, as follow the equation $H=(p-r) * d^{2}$ where, $H$ is the heterosis; $(p-r)$ is the divergence, due to the difference from allele frequencies and; $d$ is the deviations of dominance (FALCONER and MACKAY, 1996).

Recently, with global climate changes and the increasing pressure for the development of sustainable agriculture, the phosphorus use efficiency (PUE) has been becoming important, especially for tropical soils where has low availability of this nutrient. According to FRITSCHE-NETO et al. (2010) and MAIA et al. (2011), the obtaining of genotypes more PUE allows to achieve satisfactory yields with lower costs. However, the evaluation and selection based on phenotype for PUE and its components, the $\mathrm{P}$ absorption (PAE) and utilization (PUtE) efficiencies, used methods that are generally expensive and destructive to the plants. Those characteristics lead to reduction in the potential of gains to be obtained with the selection and/or hinder the evaluation of a large number of genotypes.

Several studies have attempted to relate the genetic dissimilarity, measured by DNA markers, with the hybrid performance (AGUIAR et al., 2007; FREITAS JR et al., 2006). In maize, GUIMARÃES et al., (2007) e OLIBONI et al., (2012) reported that estimates of genetic divergence were not effective at predicting the most heterotic crossings which shows that estimates of correlations between molecular variables (genetic distance) with estimates of quantitative parameters are complex, with little consistency and are difficult to interpret. However, the correlation between them is not consistent in most researchers. Furthermore, the relationship between genetic divergence and heterosis for important traits in abiotic stress conditions, such as the PUE, is still little known in tropical maize germplasm.

Thus, given the above, the aim of this study was to determine the relationship between heterosis and genetic divergence for phosphorus use efficiency in tropical maize.

\section{MATERIAL AND METHODS}

It was used two groups of inbreed lines from the germplasm bank of Programa Milho, Federal University of Viçosa - UFV. The Group I (GI) was composed of seven lines $(\mathrm{P}=1,2, \ldots, 7)$ contrasting for phosphorus use efficiency (PUE) and the Group II (GII) was composed of seven lines $\left(\mathrm{P}^{\prime}=1^{\prime}, 2\right.$ ', .., 7') contrasting for nitrogen use efficiency (NUE). Through a factorial mating design involving these two groups, were obtained 41 experimental hybrid combinations (unbalanced). The crosses were performed in a reciprocal way, with the seeds of the same combination mixed, disregarding the extra chromosomal inheritance.

Those 41 hybrid combinations obtained were evaluated in conditions of low $\mathrm{P}$ availability. The experiment was conducted in a greenhouse at UFV (2045'14"S; 4252'53" W), in October, 2010. It was used a randomized block design, with two replications.

The seeds were germinated in trays with individual cells and after emergence, one seedling of each hybrid combination was transplanted to PVC cylindrical vessels with $4 \mathrm{dm}^{3}(10 \mathrm{~cm}$ diameter $x 50 \mathrm{~cm}$ height), which constituted an experimental unit. The substrate was prepared by mixing $50 \%$ washed sand with deionized water, $37.5 \%$ of vermiculite and $12.5 \%$ of soil (horizon "B" from red-yellow oxisol). The soil was used to adsorb phosphorus and not leave it readily available to the plants.

The nutrient solution was supplied every two days, from the seventh day after seedling emergence. The $\mathrm{P}$ was supplied through triple superphosphate. To simulatea condition of reduced availability of phosphorus, were added only $34 \mathrm{mg} \mathrm{dm}^{-3}$ of $\mathrm{P}$ in the substrate. The other nutrients were supplied by nutrient solution as described by CHUN et al. (2005), without $\mathrm{P}$ addition.

The plants were harvested at vegetative stage of six completely expanded leafs (V6), 30 days after sowing. The shoots of the plant were separated from the root system and stored in paper bags. Later, was proceeded the drying process in a forced air at $60^{\circ} \mathrm{C}$ for 72 hours, where the shoots reached constant mass.

To quantify the content of $\mathrm{P}$ in each plant, were extracted samples of $0.1 \mathrm{~g}$ from the dry mass of the shoots (DMS) per plant and performed the nitropercloric digestion, according to MALAVOLTA 1989, cited by MAIA et al. (2011). The readings were 
made in a spectrophotometer at $725 \mathrm{~nm}$. The $P$ content was estimated from its tenor, extrapolating per unit of DMS and then the $P$ use efficiency and its components, the $\mathrm{P}$ absorption efficiency (PAE) and $\mathrm{P}$ utilization efficiency (PUtE), were calculated according to the proposed by MOLL et al. (1982):

$P A E=\frac{P(\text { absorved })}{P(\text { aplied })}\left(m g m g^{-1}\right), P U t E=\frac{D M S}{P(\text { absorved })}\left(m g m g^{-1}\right)$ and PUE $=P A E \times P U t E\left(m g ~ m g^{-1}\right)$.

To obtain the components of variance and the genetic parameter estimates, the data were submitted to analysis by the method of Restricted Maximum Likelihood/Best Linear Unbiased Prediction (REML/BLUP), as described by RESENDE (2007):

$\mathrm{y}=\mathrm{Xr}+\mathrm{Zm}+\mathrm{Wf}+\mathrm{Tc}+\mathrm{e}$ where, $\mathrm{y}$ is the vector of phenotypic means of the hybrid combinations; $r$ is the vector of replicate effects (assumed as fixed) added to the overall mean; $\mathrm{m}$ is the vector of the parents effects from Group II (assumed as random), which, $m \sim N(0, M)$ and $M=I \sigma_{m}^{2}$; $\mathrm{f}$ is the vector of the parents effects from Group I (assumed as random), which, $f \sim N(0, F)$ and $F=I \sigma_{f}^{2}$; $\mathrm{c}$ is the vector of the specific combining ability between Groups I and II (assumed as random), which, $c \sim N(0, C)$ and $C=I \sigma_{c}^{2}$; e is the vector of errors, which, $e \sim N(0, R)$ and $R=I \sigma_{e}^{2} . \mathrm{X}, \mathrm{Z}, \mathrm{W}$ and $\mathrm{T}$ are incidence matrices that relate, respectively, the effects of $\mathrm{r}, \mathrm{m}$ and $\mathrm{c}$ to the vector $\mathrm{y}$.

To solve the mixed model equations and obtain the genetic values, the genetic and non-genetic components of variance were assumed unknown. Thus, these were estimated by REML, using the computational statistical package SELEGEM-REML/ BLUP(RESENDE 2007).

In the genotyping of the 14 parental lines, which had more than seven generations of selfing, were used 80 microsatellite markers (SSR), as described by LABORDA et al. (2005). These were chosen for their informational content, location on chromosomes and mainly because of their association with traits of agronomic interest (MAIZEGDB - http:// www.maizegdb.org/ssr.php). For the dissimilarities analyzes were considered only the markers that showed frequency higher than $5 \%$ in the hybrid population.

To obtain the genetic dissimilarity among the parental lines it was used the method of codominant/multialelic analysis, as described by CRUZ (2008), considering the following expression:

$$
S_{i i^{\prime}}=\frac{1}{2} \sum_{j=1}^{L} p_{j} c_{j} \text {, where, } p_{j}=\frac{a_{j}}{A} \quad \text { is the }
$$

weight associated with locus $j$, given by: $\mathrm{a}_{\mathrm{j}}$ - total number of alleles in locus $j$; A - total number of alleles observed, $\mathrm{L}$ - total number of loci or markers and $\mathrm{c}_{\mathrm{j}}$ - the number of alleles shared between pairs of data $i \mathrm{e} i$.

The relationship between heterosis and genetic divergence for PUE and its components PAE and PutE was estimated by Pearson correlation, where, were used the specific combining ability (SCA) for these traits and the genetic dissimilarity (by molecular markers) among the parental lines. In this context, the SCA was considered as a parameter for the estimation of heterosis for a particular crossing and genetic dissimilarity to estimate the genetic divergence between the parental lines (CRUZ et al., 1989).

\section{RESULTS AND DISCUSSION}

In the results it was observed that the parents from GI showed significant differences for the effect of general combining ability (GCA) for the components of PUE (Table 1). Moreover, the same was not observed in parents from GII. These genetic differences indicate the existence of additive genetic variability among then and that parents from GI contribute differently for the transmission of alleles that control the expression of PUE and its components.

Regarding the effects of specific combining ability (SCA), significant differences were observed for PUE and PAE, indicating that the hybrid combinations showed significant deviations from the average behavior of their parents. Further, differences of great magnitude were found between the heritability estimates in broad and narrow sense. Thus, the genotypic variance is mainly explained by the variance of dominance deviations, evidenced by high values of the ratio $\hat{\sigma}_{d}^{2} / \hat{\sigma}_{a}^{2}$. This demonstrates that the nonadditive effects have greater importance for PUE, as reported by CHEN et al. (2009), who identified QTL in maize related with this traits showed effects predominantly of partial dominance or overdominance. Therefore, larger genetic gain must be obtained for these traits through the use of strategies of interpopulational breeding (FALCONER \& MACKAY, 1996).

The coefficients of variation were relatively high for the traits evaluated (FRITSCHE-NETO et al., 2012). However, they are in the range observed for this 


\begin{tabular}{|c|c|c|c|}
\hline Effect & PAE & PUtE & PUE \\
\hline $\mathrm{GCA}_{(\mathrm{GI})}{ }^{1}$ & $2.72 *$ & $3.24 *$ & $1.22^{\mathrm{ns}}$ \\
\hline ECA (GII) ${ }^{1}$ & $0.00^{\mathrm{ns}}$ & $0.82^{\mathrm{ns}}$ & $0.00^{\text {ns }}$ \\
\hline ECA GI x GII ${ }^{1}$ & $3.14 *$ & $0.51^{\mathrm{ns}}$ & $2.99 *$ \\
\hline$h_{a}^{2}$ & 0.06 & 0.34 & 0.04 \\
\hline$h_{g}^{2}$ & 0.15 & 0.42 & 0.32 \\
\hline$\hat{\sigma}_{d}^{2} / \hat{\sigma}_{a}^{2}$ & 1.29 & 0.25 & 6.95 \\
\hline Mean & 0.02 & 517.29 & 8.11 \\
\hline $\mathrm{CV}(\%)$ & 43.78 & 12.94 & 28.61 \\
\hline $\mathrm{CVg}(\%)$ & 18.52 & 10.97 & 19.44 \\
\hline
\end{tabular}

${ }^{1}$ Values obtained by a likelihood ratio test (LRT). Significant at *** $\mathrm{P} \leq 0.01$, ** $\mathrm{P} \leq 0.05, * \mathrm{P} \leq 0.10$ and ${ }^{\mathrm{NS}}$ no significant by $\chi^{2}$ test with 1 degree of freedom.

kind study with abiotic stress (MAIA et al., 2011) which indicates good experimental precision and reliability about the estimates.

According to WHANG et al. (2010) the genetic variability detected for PUE in tropical maize under low availability of $\mathrm{P}$, is due mainly by PAE, where, similar result was observed in this study. In addition, CORRALES et al. (2007) observed that under both, low and high $\mathrm{P}$ availability, the component of highest importance to PUE is the PAE, and the effect of PUtE may be neglected. To this authors, may be have happened the loss of allelic diversity to PUtE, since the modern cultivars, almost entirely, were selected for the high responsiveness to fertilization. Based on these results, the following analyzes were performed only to PUE and its component PAE.

The significant effect of SCA estimates showed the importance of genes with non-additive effects, which proves the importance of heterosis. In these, there were great variation and positive and negative estimates for the traits PUE and PAE (Table 2).

Through correlation analysis between the genetic distance, obtained by molecular markers, and the SCA, it was observed that for PUE there is low, positive and significant relationship between heterosis and genetic divergence $(0.32 * *)$. The same was not observed for PAE $\left(0.14^{\text {ns }}\right)$. Despite the correlation being significant for PUE, it is important to notice its very low magnitude, which leads to a very low coefficient of determination $(0.10)$. These results indicates that it is not possible to determine with accuracy, by molecular markers, if the crosses would produce hybrids with the highest heterosis for PUE or PAE. Similar results were observed by GUIMARÃES et al. (2007) in maize and AGUIAR et al. (2007) in Eucalyptus.

According to FALCONER \& MACKAY (1996) heterosis is composed of: $i$ ) dominance deviations different from zero, $i$ ) genetic divergence and iii) complementarity. Thus, this lack of relationship between genetic dissimilarity and heterosis, can be attributed mainly to the low accuracy of the markers to predict the complementarity among the parent in crosses, ie, the low accuracy to predict the dominance deviations by molecular markers. It is evidenced in the case of combination $5 \times 5$, which presents the highest measure of dissimilarity between their parents, but only the $25^{\text {th }}$ position among all 41 hybrid combinations evaluated for PUE. Similarly, the combination $6 \times 5^{\prime}$ showed the highest SCA for PUE, but only the $22^{\text {th }}$ showed higher dissimilarity between their parents.

\section{CONCLUSION}

There is no relationship between genetic divergence and heterosis for phosphorus use efficiency and its components in tropical maize. 
Table 2 - Estimates of specific combining ability and genetic dissimilarity for phosphorus absorption (PAE) and use (EUP) efficiencies in 41 hybrid combinations of tropical maize from 14 parental lines divided in two groups of seven genitors

\begin{tabular}{|c|c|c|c|}
\hline Hybrid combination & Dissimilarity & PAE & PUE \\
\hline $1 \times 11^{\prime}$ & 0.786 & 0 & 0.119 \\
\hline $1 \times 2^{\prime}$ & 0.783 & -0.001 & -0.787 \\
\hline $1 \times 3^{\prime}$ & 0.674 & 0 & 0.425 \\
\hline $1 \times 5^{\prime}$ & 0.735 & 0 & 0.595 \\
\hline $1 \times 6^{\prime}$ & 0.79 & 0.001 & 1.059 \\
\hline $1 \times 7^{\prime}$ & 0.759 & 0 & -0.888 \\
\hline $2 \times 1^{\prime}$ & 0.685 & 0 & 0.194 \\
\hline $2 \times 4^{\prime}$ & 0.763 & 0 & 0.245 \\
\hline $2 \times 5^{\prime}$ & 0.797 & 0 & 0.943 \\
\hline $2 \times 6^{\prime}$ & 0.725 & -0.001 & -1.036 \\
\hline $3 \times 1^{\prime}$ & 0.641 & 0 & -0.563 \\
\hline $3 \times 2^{\prime}$ & 0.783 & 0 & -0.427 \\
\hline $3 \times 4^{\prime}$ & 0.705 & 0 & -0.028 \\
\hline $3 \times 5^{\prime}$ & 0.817 & 0 & 0.274 \\
\hline $3 \times 6^{\prime}$ & 0.685 & -0.001 & -2.296 \\
\hline $3 \times 7^{\prime}$ & 0.786 & 0 & 0.047 \\
\hline $4 \times 1^{\prime}$ & 0.749 & 0 & 0.697 \\
\hline $4 \times 2^{\prime}$ & 0.688 & 0.002 & 0.911 \\
\hline $4 \times 4^{\prime}$ & 0.702 & 0 & -0.633 \\
\hline $4 \times 5^{\prime}$ & 0.746 & 0 & -1.388 \\
\hline $4 \times 6^{\prime}$ & 0.773 & 0 & -0.121 \\
\hline $4 \times 7^{\prime}$ & 0.756 & -0.001 & -1.387 \\
\hline $5 \times 1^{\prime}$ & 0.688 & 0 & -0.697 \\
\hline $5 \times 2^{\prime}$ & 0.739 & 0 & 0.138 \\
\hline $5 \times 3^{\prime}$ & 0.708 & 0 & 0.327 \\
\hline $5 \times 4^{\prime}$ & 0.759 & 0 & -0.032 \\
\hline $5 \times 5^{\prime}$ & 0.851 & 0 & -0.153 \\
\hline $5 \times 6^{\prime}$ & 0.803 & 0.001 & 1.66 \\
\hline $5 \times 7^{\prime}$ & 0.783 & 0 & -0.573 \\
\hline $6 \times 1^{\prime}$ & 0.644 & 0 & -1.359 \\
\hline $6 \times 2^{\prime}$ & 0.803 & 0 & -0.003 \\
\hline $6 \times 3^{\prime}$ & 0.732 & 0 & -0.502 \\
\hline $6 \times 4^{\prime}$ & 0.807 & 0.002 & 1.645 \\
\hline $6 \times 5^{\prime}$ & 0.749 & 0.001 & 2.11 \\
\hline $6 \times 6^{\prime}$ & 0.79 & 0 & 0.894 \\
\hline $7 \times 2^{\prime}$ & 0.707 & 0 & 0.083 \\
\hline $7 \times 3^{\prime}$ & 0.776 & 0 & -0.293 \\
\hline $7 \times 4^{\prime}$ & 0.722 & 0 & 0.899 \\
\hline $7 \times 5^{\prime}$ & 0.742 & 0 & -1.213 \\
\hline $7 \times 6^{\prime}$ & 0.783 & 0.001 & 1.82 \\
\hline $7 \times 7^{\prime}$ & 0.769 & 0 & -0.704 \\
\hline
\end{tabular}

\section{ACKNOWLEDGMENTS}

The Coordenação de Aperfeiçoamento Pessoal de Nível Superior (CAPES), Conselho Nacional de Desenvolvimento Científico e Tecnológico (CNPq) and Fundação de Amparo à Pesquisa do estado de Minas Gerais (FAPEMIG) for the financial support.

\section{REFERENCES}

AGUIAR, M.S. et al. Potencial de híbridos entre clones-elite de eucalipto por meio de marcadores microssatélites. Pesquisa Agropecuária Brasileira, v.42, p.1007-1012, 2007. Available from: <http://dx.doi.org/10.1590/S0100-204X2007000700013>. Accessed: Mar. 2, 2012. doi: 10.1590/S0100204X2007000700013.

Ciência Rural, v.43, n.1, jan, 2013. 
CARVALHO, L.P. et al. Análise da diversidade genética entre acessos de banco ativo de germoplasma de algodão. Pesquisa Agropecuária Brasileira, v.38, n.10, p.1149-1155, 2003. Available from: <http:/ /dx.doi.org/10.1590/S0100-204X2003001000003>. Accessed: Jul. 4, 2012. doi: 10.1590/S0100-204X2003001000003.

CHEN, J.Y. et al. Identification of QTLs for phosphorus utilization efficiency in maize (Zea mays L.) across P levels. Euphytica, v.167, p.245-252, 2009. Available from: <http:// www.springerlink.com/content/ht302641288162j5/>. Accessed: Fev. 27, 2012. doi: 10.1007/s10681-009-9883-x.

CHUN, L. et al. Genetic analysis of maize root characteristics in response to low nitrogen stress. Plant and Soil, v.276, p.369-382, 2005. Available from: <http:// www.springerlink.com/content/72103712u0177307/>. Acessed: Mar. 3, 2012. doi: 10.1007/s11104-005-5876-2.

CORRALES, I. et al. Phosphorus efficiency and root exudates in two contrasting tropical maize varieties. Journal Plant Nutrition, v.30, p.887-900, 2007. Available from: <http:// www.tandfonline.com/doi/abs/10.1080/15226510701375085>. Accessed: Mar. 05, 2012. doi: 10.1080/15226510701375085.

CRUZ, C.D. Programa genes diversidade genética: aplicativo computacional em genética e estatística. Viçosa: UFV, 2008. 278p.

CRUZ, C.D. et al. Comparação de alguns métodos de análise dialélica. Revista Brasileira de Genética, v.12, p.425-438, 1989. Available from: <http://web2.sbg.org.br/gmb/ edicoesanteriores/v12n2/pdf/a22v12n2.pdf >. Acessed: Mar. 3, 2012 .

FALCONER, D.S.; MACKAY, T.F.C. Introduction to quantitative genetics. 4.ed. Edinburgh: Longman, 1996. 462p.

FREITAS JR, SP. et al. Capacidade combinatória em milhopipoca por meio de dialelo circulante. Pesquisa Agropecuária Brasileira, v.41, p.1599-1607, 2006. Available from: <http:/ /dx.doi.org/10.1590/S0100-204X2006001100005>. Accessed: Mar. 2, 2012. doi: 10.1590/S0100-204X2006001100005.

FRITSCHE-NETO, R. et al. Herança de caracteres associados à eficiência de utilização do fósforo em milho. Pesquisa Agropecuária Brasileira, v.45, p.465-471, 2010. Available from: <http://dx.doi.org/ 10.1590/S0100-204X2010000500005>. Accessed: Mar. 2, 2012. doi: 10.1590/S0100-204X2010000500005.
FRITSCHE-NETO, R. et al. Updating the ranking of the coefficients of variation from maize experiments. Acta Scientiarum. Agronomy, v.34, p.99-101, 2012. Available from: <http://dx.doi.org/10.4025/actasciagron.v34i1.13115>. Accessed: Mar. 3, 2012. doi: 10.4025/actasciagron.v34i1.13115.

GUIMARÃES, P.S. et al. Correlação da heterose de híbridos de milho com divergênciagenética entre linhagens. Pesquisa Agropecuária Brasileira, v.42, p.811-816, 2007. Available from: <http://dx.doi.org/ 10.1590/S0100-204X2007000600007>. Accessed: Mar. 3, 2012. doi: 10.1590/S0100-204X2007000600007.

LABORDA, P.R. et al. Tropical maize germoplasm: what can we say about its genetic diversity in the light of molecular markers? Theoretical and Applied Genetics, v.111, p.12881299, 2005. Available from: <http://www.springerlink.com/ content/q057008902368n70/>. Accessed: Mar. 5, 2012. doi: $10.1007 / \mathrm{s} 00122-005-0055-7$.

MAIA, C. et al. The difference between breeding for nutrient use efficiency and for nutrient stress tolerance. Crop Breeding and Applied Biotechnology, v.11, p.270-275, 2011. Available from: <http://dx.doi.org/10.1590/S 1984-70332011000300010>. Accessed: Mar. 2, 2012. doi: 10.1590/S1984-70332011000300010.

MALAVOLTA, E. et al. Avaliação do estado nutricional de plantas. Piracicaba: Potafos, 1989. 201p.

MOLL, R.H. et al. Analysis and interpretation of factors which contribute to efficiency of nitrogen utilization. Agronomy Journal, v.74, p.562-564, 1982. Available from: <https:// www.soils.org/publications/aj/abstracts/74/3/AJ0740030562>. Accessed: Mar. 3, 2012.

OLIBONI, R. et al Genetic divergence among maize hybrids and correlations with heterosis and combining ability. Acta Scientiarum. Agronomy, v.34, n.1, p.37-44, 2012. Available from: <http://dx.doi.org/10.1590/S1807-86212012000100006> Accessed: Jul. 3, 2012. doi: 10.1590/S1807-86212012000100006.

RESENDE, M.D.V. SELEGEN-REML/BLUP: sistema estatístico e seleção genética computadorizada via modelos lineares mistos. Colombo: EMBRAPA Florestas, 2007. 361p.

WHANG, X. et al. Acquisition or utilization, which is more critical for enhancing phosphorus efficiency in modern crops? Plant Science, v.179, p.302-306, 2010. Available from: <http://dx.doi.org/10.1016/j.plantsci.2010.06.007>. Accessed: Mar. 5, 2012. doi: 10.1016/j.plantsci.2010.06.007. 